\title{
KINETICS OF GASEOUS TOLUENE ADSORPTION ON CANDLENUT SHELL ACTIVATED CARBON
}

\author{
Audy D. Wuntu' ${ }^{1)}$, Vanda S. Kamu ${ }^{1)}$ \\ ${ }^{1)}$ Program Studi Kimia FMIPA Universitas Sam Ratulangi \\ Jl. Kampus Unsrat Manado 95115 \\ e-mail: wuntudenny@unsrat.ac.id; vandakamu05@gmail.com
}

\begin{abstract}
Adsorption kinetics of gaseous toluene on activated carbon prepared from candlenut shell had been studied. The research was performed by examining adsorption data, which was obtained in previous research, over several rate equations, which were: (1) Lagergren's pseudo first order rate equation, (2) Ho's pseudo second order rate equation, (3) Elovich's equation, and (4) persamaan Ritchie's equation. The result showed that the data of toluene adsorption on candlenut shell activated carbon fits the Ho's pseudo second order rate equation and, hence, the model is the most applicable model for the adsorption. Calculation from linear regression of Ho's pseudo second order rate equation gave the equilibrium adsorption capacity value of $56,069 \mathrm{mg} \mathrm{g}^{-1}$, second order rate constant of $3,54 \times 10^{-4} \mathrm{~g} \mathrm{mg}^{-1} \mathrm{~min}^{-1}$, and initial adsorption rate of $1,112 \mathrm{mg} \mathrm{g}^{-1} \mathrm{~min}^{-1}$.
\end{abstract}

Keywords: adsorption, candlenut, activated carbon, toluene

\section{KINETIKA ADSORPSI GAS TOLUENA PADA KARON AKTIF TEMPURUNG KEMIRI}

\begin{abstract}
ABSTRAK
Studi mengenai aspek kinetika adsorpsi toluena pada arang aktif yang terbuat dari tempurung kemiri telah dilakukan. Penelitian dilakukan dengan menguji data adsorpsi yang telah diperoleh pada penelitian terdahulu menggunakan empat persamaan laju adsorpsi, yaitu (1) persamaan laju pseudo order pertama Lagergren, (2) persamaan laju pseudo order kedua Ho, (3) persamaan Elovich, dan (4) persamaan Ritchie. Hasil kajian menunjukkan bahwa model kinetika dengan persamaan laju pseudo order kedua Ho adalah yang paling sesuai diaplikasikan untuk adsorpsi gas toluena pada arang aktif tempurung kemiri. Dari persamaan linear untuk model kinetika pseudo order kedua Ho diperoleh nilai kapasitas adsorpsi pada kesetimbangan sebesar 56,069 $\mathrm{mg} \mathrm{g}^{-1}$, konstanta adsorpsi sebesar $3,54 \times 10^{-4} \mathrm{~g} \mathrm{mg}^{-1}$ menit $^{-1}$, dan laju adsorpsi awal sebesar $1,112 \mathrm{mg} \mathrm{g}^{-1}$ menit $^{-1}$.
\end{abstract}

Kata kunci: adsorpsi, kemiri, karbon aktif, toluena

\section{INTRODUCTION}

Adsorption kinetics is one of the aspects investigated in evaluating characteristics of an adsorbent applied especially for environmental remediation. Several models of adsorption kinetics have been developed in order to estimate the rate with which an adsorbent removes substances from the system. Some of the models have been reviewed by Qiu et al. (2009) and Ho (2006), those are : (1) Lagergren's pseudo first order rate equation that has been applied in describing the adsorption characteristics of pollutants from wastewater, (2) Ho's pseudo second order rate equation that has been applied successfully in characterizing the adsorption of metal ions and organic substances from aqueous solutions, (3) Elovich's equation which is applied mainly in the adsorption of gas onto solid systems, and (4) Ritchie's equation which is widely used also in gas-solid systems.

In this research, these rate equations were evaluated in order to describe the adsorption of gaseous toluene on activated charcoal prepared from candlenut (Aleurites mollucana) shell. In previous research (Bukasa et al., 2012), it was found that this material has adsorption capacity of 0.094 $\mathrm{cm}^{3} / \mathrm{g}$ for gaseous toluene and the adsorption 
equilibrium was reached in 300 minutes. The adsorption data obtained in the previous research was used in the calculation using the four rate equations to meet the model most applicable for the adsorption of toluene on candlenut shell activated carbon.

\section{METHODOLOGY}

Preparation of candlenut shell activated carbon and experiment of toluene adsorption on the adsorbent was described in the previous article (Bukasa et al., 2012). Adsorption data in terms of the time required to reach adsorption equilibrium state was used to evaluate rate equation most applicable for this adsorption. Rate equations evaluated in this research were:

(1) Pseudo first order rate equation

This rate equation is presented as:

$$
\log \left(q_{e}-q_{t}\right)=\log q_{e}-\left(\frac{k}{2.303}\right) t
$$

where $q_{\mathrm{e}}$ is the adsorption capacity at equilibrium, $q_{\mathrm{t}}$ is the adsorption capacities at time $t$, and $\mathrm{k}$ is the pseudo first order rate constant. Plot of $\log \left(q_{\mathrm{e}}-q_{\mathrm{t}}\right)$ versus time $t$ would give a straight line and the coefficient of determination, $\mathrm{R}^{2}$, could be revealed.

(2) Ho's Pseudo second order rate equation which is expressed in the form:

$$
\frac{t}{q_{t}}=\frac{1}{V_{0}}+\frac{1}{q_{e}} t
$$

where $V_{0}$ is initial adsorption rate which equals to pseudo second order rate constant multiplied by $q_{\mathrm{e}}^{2}$. Plot of $t / q_{\mathrm{t}}$ versus $t$ should result in a straight line and its corresponding coefficient of determination $\mathrm{R}^{2}$.

(3) Elovich's equation

Elovich's equation is widely used to elucidate the adsorption of gas particles onto solid systems and has the expression of:

$q=\alpha \ln (a \alpha)+\alpha \ln t$

where $q$ is the amount of gas adsorbed at time $t, \alpha$ is desorption constant, and $a$ is initial adsorption rate. A straight line and its corresponding $\mathrm{R}^{2}$ should be obtained by plotting $q$ against $\ln t$.

(4) Ritchie's equation

Ritchie's equation is also widely used in the adsorption of gas particles onto solid systems. The expression of this equation is :

$$
\frac{q_{\infty}}{q_{\infty}-q}=\alpha t+1
$$

where $q$ and $q_{\infty}$ are the amount of gas adsorbed at time $t$ and after an infinite time, respectively, and $\alpha$ is the rate constant. This equation is simply a linear equation and plot of $q_{\infty} /\left(q_{\infty}-q\right)$ versus $t$ would produce a straight line.

Given that the value of coefficient of determination $\mathrm{R}^{2}$ describes how well a regression line fits a set of data, the rate equation that has highest value of $\mathrm{R}^{2}$ should be the best expression to be applied for the adsorption of toluene on candlenut shell activated carbon. Adsorption data used in the evaluation of adsorption kinetics is shown in Table 1.

Table 1. Adsorption data of toluene on candlenut activated carbon (after Bukasa et al., 2012)

\begin{tabular}{|c|c|c|}
\hline time (min) & $\begin{array}{c}\text { mass of } \\
\text { activated } \\
\text { carbon }(\mathrm{g})\end{array}$ & $\begin{array}{c}\text { mass of } \\
\text { adsorbed } \\
\text { toluene }(\mathrm{g})\end{array}$ \\
\hline 60 & 10.0054 & 0.3559 \\
\hline 120 & 10.0069 & 0.3861 \\
\hline 180 & 10.0078 & 0.4448 \\
\hline 240 & 10.0035 & 0.4904 \\
\hline 300 & 10.0072 & 0.5206 \\
\hline 600 & 10.0049 & 0.4710 \\
\hline 1080 & 10.0054 & 0.5146 \\
\hline 1440 & 10.0058 & 0.5620 \\
\hline
\end{tabular}

\section{RESULTS AND DISCUSSION}

The linear regression analysis of adsorption data in relation to pseudo first order rate equation, pseudo second order rate equation, Elovich's equation, and Ritchie's equation are displayed in Figure 1, 2, 3, and 4 respectively.

It is obviously noticed that the linear regression analysis with respect to Ho's pseudo second order rate equation generates a straight line that best fit to the data of adsorption of gaseous toluene on candlenut shell activated carbon. It, unexpectedly, does not fit the Elovich's or Ritchie's equation which are widely used in describing the adsorption of gaseous particles on solid systems. The coefficients of determinations are $0.994,0.784,0.405$, and 0.254 for pseudo second order, Elovich's, pseudo first order, and Ritchie's equation. 


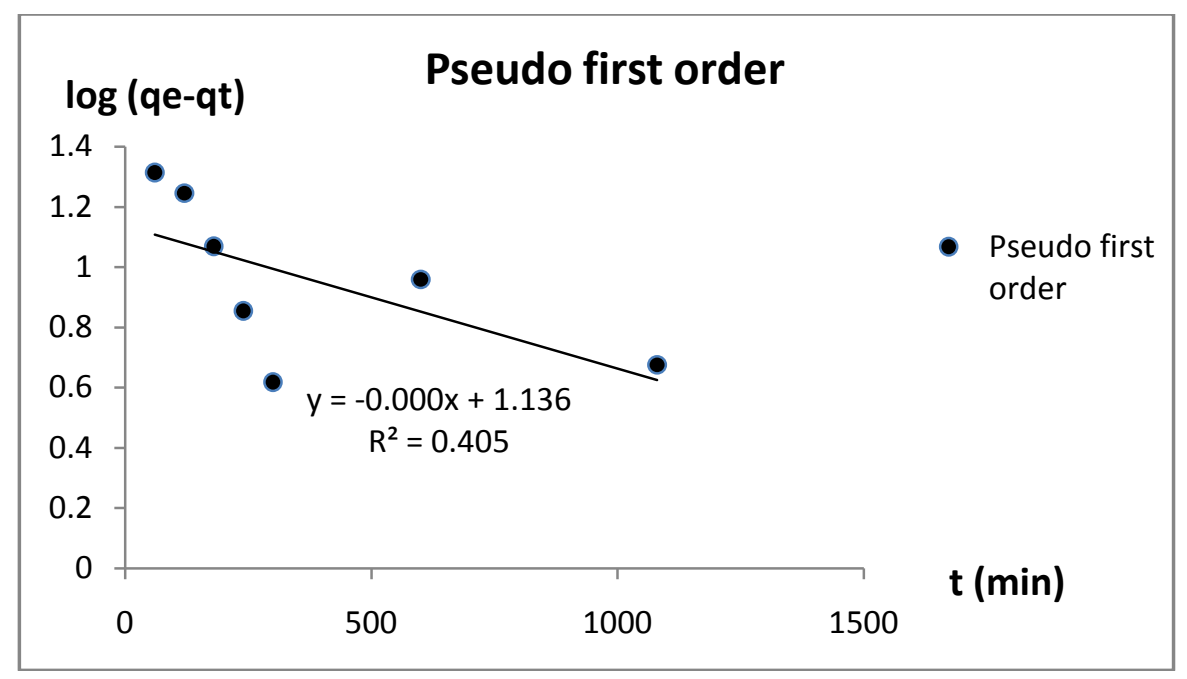

Figure 1. Plot of $\log \left(\mathrm{q}_{\mathrm{e}}-\mathrm{q}_{\mathrm{t}}\right)$ vs. $\mathrm{t}$ and its corresponding $\mathrm{R}^{2}$ according to pseudo first order rate equation

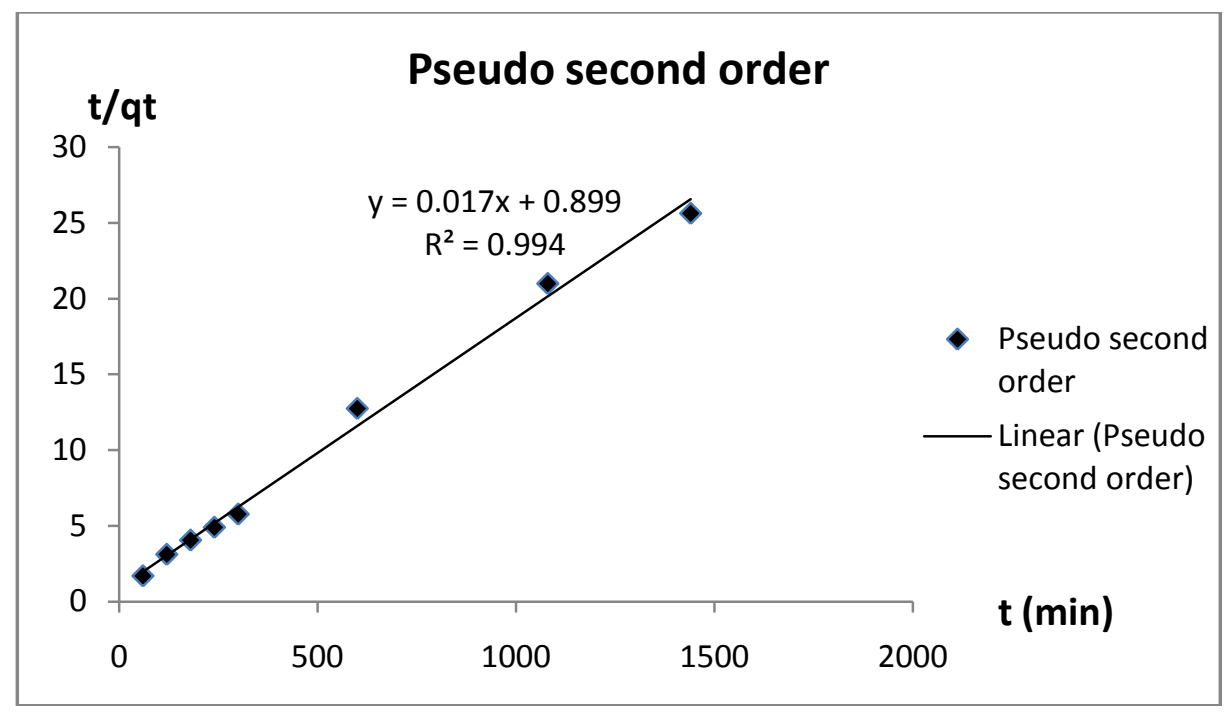

Figure 2. Plot of $t / q_{\mathrm{t}} v s . \mathrm{t}$ and its corresponding $\mathrm{R}^{2}$ according to pseudo second order rate equation

Pseudo second order has been succesfully applied to the adsorption of metal ions, dyes, herbicides, oils, and organic substances from aqueous solutions (Ho, 2006). Indeed, Ho's pseudo second order equation, developed based on the adsorption capacity on the solid phase, is claimed to have ability in predicting the behavior above the whole range of analysis involving a pseudo second order equation and it confirms chemisorption as the rate controlling step (Ho and McKay, 1998).
However, Bukasa et al. (2012) found that the adsorption energy involved in adsorption of toluene on the candlenut shell activated carbon implies that it is a physical adsorption. This might be resulted from the calculation of adsorption energy using DubininRaduskevich (DR) equation which is based on the Theory of Volume Filling of Micropores (TVFM).

In TVFM, particles are not adsorbed to form layers but through volume filling of 
micropores which results in lower energy of adsorption. This model is different from the description of Ho's pseudo second order equation which is based on the adsorption of divalent metals on moss peat. The assumption is that the divalent metal ions are adsorbed chemically through sharing or exchange of electrons between the metal ions and peat (Ho, 2006). The difference is evident as the adsorption capacity of $81.78 \mathrm{mg} \mathrm{g}^{-1}$ (equivalent to $0.094 \mathrm{~cm}^{3} \mathrm{~g}^{-1}$ ) resulted from Dubinin-Raduskevich equation (Bukasa et al, 2012) is compared to that of $56.069 \mathrm{mg} \mathrm{g}^{-1}$ resulted from Ho's pseudo second order rate equation. Volume filling of activated carbon micropores results in much higher adsorption capacity which is much weaker in energy of adsorption.

Using Ho's pseudo second order rate equation, the second order rate constant $\mathrm{k}$ and initial adsorption rate could be determined. In this case, the rate constant $\mathrm{k}$ is $3.54 \times 10^{-4} \mathrm{~g}$ $\mathrm{mg}^{-1} \mathrm{~min}^{-1}$ and initial adsorption rate $\mathrm{V}_{0}$ is $1.112 \mathrm{mg} \mathrm{g}^{-1}$ menit $^{-1}$.

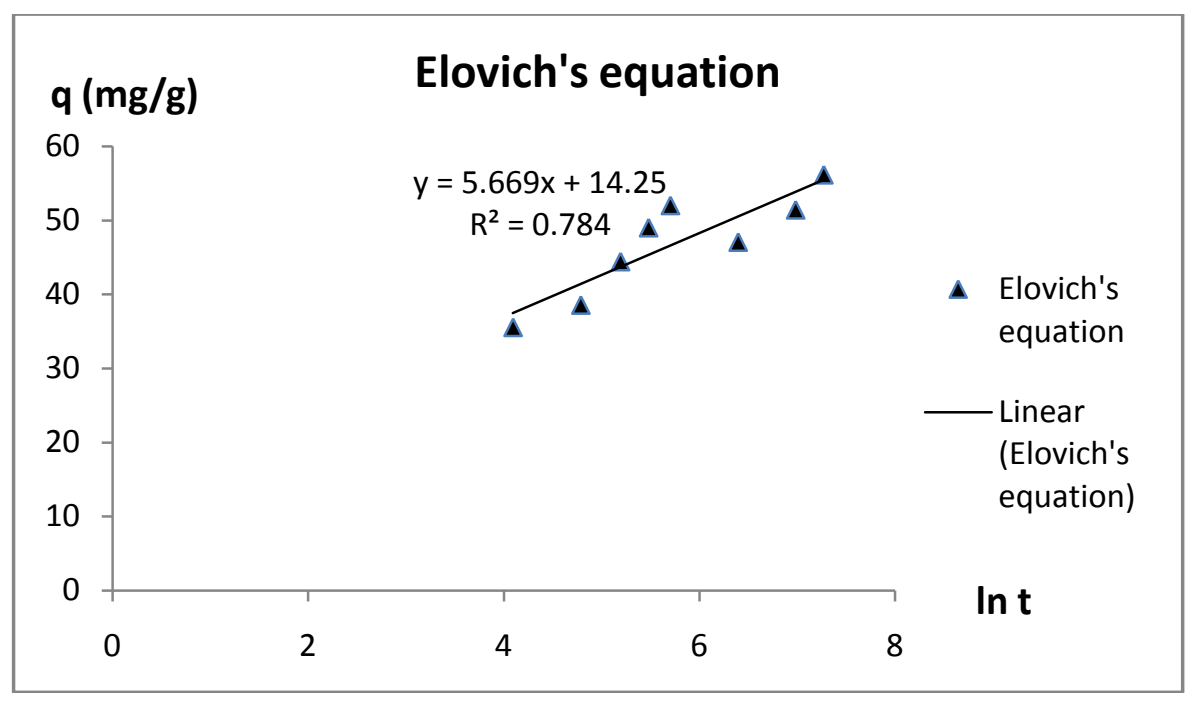

Figure 3. Plot of $q v s$. $\ln \mathrm{t}$ and its corresponding $\mathrm{R}^{2}$ according to Elovich's equation

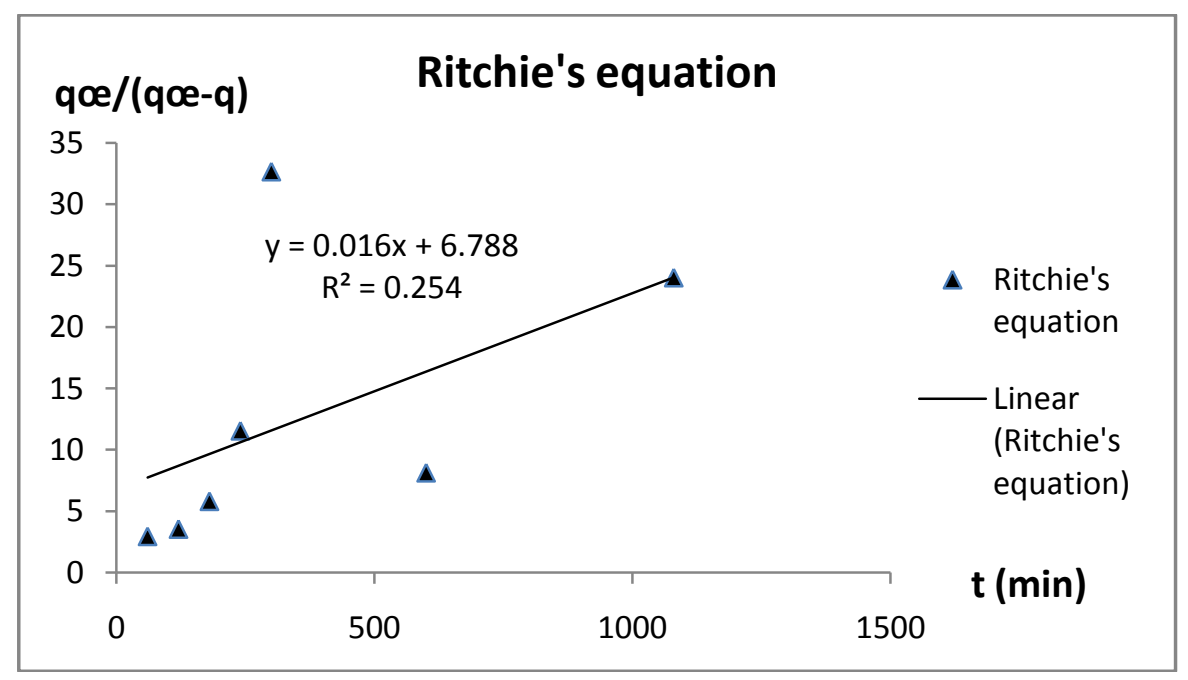

Figure 4. Plot of $q_{\infty} /\left(q_{\infty}-q\right) v s$. ln $t$ and its corresponding $\mathrm{R}^{2}$ according to Rirchie's equation 


\section{CONCLUSION}

The adsorption data of gaseous toluene on activated carbon prepared from candlenut shell fits the Ho's pseudo second order rate equation. This kinetic model confirms the chemical adsorption involved as the rate controlling step despite the data of adsorption energy which validates the involvement of physical adsorption of toluene on candlenut shell activated carbon. However, different assumptions used in different equations in calculating the two parameters could be the source of this inconsistency.

\section{REFERENCES}

Bukasa, D. A. . S. J. Koleangan, A. D. Wuntu. 2012. Adsorpsi Toluena pada Arang Aktif Tempurung Kemiri. Jurnal Ilmiah Sains. 12(2):93-99.

Ho, Y. S., G. McKay. 1998. A Comparison of Chemisorption Kinetic Models Applied to Pollutant Removal on Various Sorbents. Trans IChemE. 76:332-340.

Ho, Y. S. 2006. Review of Second-Order Models for Adsorption Systems. $J$. Hazard Mater. 136:681-689.

Qiu, H., L. Lv, B. C. Pan, Q. J. Zhang, W. M. Zhang, Q. X. Zhang. 2009. Critical Review in Adsorption Kinetic Models. J Zhejiang Univ Sci A. 10(5):716-724. 